\title{
IS THERE WORKING PROFESSIONALS' SUPPORT FOR RECOMMENDING STUDENTS DOUBLE MAJOR IN ACCOUNTING AND INFORMATION SYSTEMS?
}

\author{
Orion Welch, St. Mary’s University, owelch@stmarytx.edu \\ Tom Madison, St. Mary’s University, tmadison@stmarytx.edu \\ Sandra Welch, University of Texas at San Antonio, sandra.welch@utsa.edu
}

\begin{abstract}
This paper examines current accounting and finance professionals' preferences regarding the type of degree acquired by beginning professional accounting staff prior to employment within their organization. Specifically, we investigated to what extent a double undergraduate degree in accounting and information systems was identified as a desired degree for entry level in the field. The survey population was 2,300 individuals who were members of a large, regional CPA society in south Texas, members of the Institute of Management Accountants in the same area, or employers who had interviewed prospective employees on St. Mary's University's campus during the previous three years. While accounting was the preferred single major, $39 \%$ of 104 respondents who identified a second discipline, preferred the double major of accounting and information systems. Of this set of respondents, 75\% were employed in industry, finance, government, or "other" rather than in public accounting firms.
\end{abstract}

Keywords: academic choice, career choice, double major, information systems education.

\section{INTRODUCTION}

Studies by Pollacia and Lomerson [8] and Brown [4] have documented a significant decline in enrollment in computer science and information systems majors since 2000. As a result of this decline, CIS and MIS programs have examined alternative ways to market the majors to students. Brown's [4] study suggested that marketing information systems as a double major could be a way to interest students in the information systems major. This might be particularly attractive to accounting majors who live in states that require completion of 150 semester hours of credit prior to sitting for the CPA examination. Students have several options for achieving this 150-hour requirement. Typical approaches include 150-hour single major bachelor's degree, double major undergraduate bachelor's degrees, master's degree in accounting, master's degree in taxation, and master's in business administration.
There is substantial commentary in accounting education circles that could be interpreted as support for the accounting/information systems double major. The American Institute of Certified Public Accountants (AICPA) has included learning to "leverage technology" as an important skill for those wishing to enter the accounting profession. The AICPA's Core Competency Framework suggests that technology skills are an essential element of personal competencies, functional competencies, and the development of broad business understanding, all three of which are critical for the professional success of young accounting professionals [1].

The substantial importance with which the AICPA views the ability to leverage technology is illustrated by the fact that several technology topics are now covered in the CPA examination. These topics include roles and responsibilities within the information technology function; the role of business information systems; and information technology fundamentals, such as hardware, software, data structure, systems operation, and database management [2]. Finally, an exhaustive study of accounting educators' and accounting professionals' opinions about accounting education by Albrecht and Sack [3] recommended consideration of joint accounting/information systems degrees. Although Albrecht and Sack were examining revamping the accounting degree to include fewer traditional accounting courses, the 150 -hour requirement for the CPA exam makes the double degree in accounting and information systems a viable option for accounting majors.

The foregoing discussion explains why the accounting/information systems degree may be attractive to an accounting major. In addition, the impact of recent changes in the regulatory environment adds further impetus for students to consider a double major. There has been a tremendous increase in the demand for internal and information technology (IT) auditors, driven in part by passage of the Sarbanes-Oxley Act. This development in the employment market may make a double major in accounting and information systems 
more attractive to those whose first choice might have been a degree in accounting or in information systems only [7].

Thus, the 150-hour CPA examination requirement, contemporary critiques of accounting education, and the increased regulatory environment may influence accounting degree programs to emphasize information systems as a second major. In addition, the market for IT auditors spurred by the regulatory environment also may influence CIS and MIS degree programs to emphasize accounting as a second major.

Albrecht and Sack [3] suggest that the business environment is rapidly changing due to globalization and changing technology. As a result, accounting faculty must continuously evaluate their program in order to insure that they are preparing graduates with the skills and content knowledge needed by today's accounting professional. An essential element of program assessment must always be the consideration of major stakeholders, and a key stakeholder is the employers of a program's graduates. We therefore designed this study to determine employers' opinions about preferred degrees for entry level accounting professionals.

\section{THE SAMPLE}

The research method in this study was a survey, described and discussed in the next section of this paper. In order to sample employers, we distributed the survey to 2,300 individuals from three separate groups: members of a large, regional CPA society in south Texas, members of the Institute of Management Accountants in the same geographic area, and employers who had interviewed students for entry-level accounting or finance positions at the St. Mary's University's campus during the previous three years. Thus, our sample contained practicing accounting/finance professionals in certified public accounting firms as well as those employed in industry and government.

The sample group was chosen to obtain a broad representation of the various types of accounting jobs. In prior studies, restricting the sample to practicing CPAs has generated concerns about the validity of results. For example, the Albrecht and Sack [3] study focused on "Big 4" (then "Big 5") and large, research university viewpoints, but many accounting students do not matriculate in large, research institutions and most will not be employed in "Big 4" firms. For instance, Huefner [6] reports that $54 \%$ of the membership of the AICPA is composed of sole practitioners. Given that small firms are the predominant form of public accounting practice, a sample drawn from CPA organization membership lists will result in a broader representation of accounting firms.

The primary method for administering the survey was the use of a web-based instrument in which respondents were asked via email to access the web site and complete the survey electronically. For a small set without available active email addresses, a paper survey was distributed via traditional mail. Usable surveys were returned by 464 individuals, a response rate of 20.2\%. Albrecht and Sack [3] report a response rate of approximately 20\%. Burnett [5] reports $27.6 \%$ rate from employers and $21.7 \%$ from private corporations and non-Big 4 firms. Ulrich, Michenzi and Blouch [10] report a response rate of $27.2 \%$ from a random sample of national firms with at least 50 professionals. Sedki, Madison, and Treacy [9] report $16 \%$ responding from a random sample of CPA firms registered with the Texas State Board of Public Accountancy.

Our respondents represent a wide range of CPA firm/organization sizes. The median number of accounting professionals in public accounting firms was 11. Forty-six of the 199 public accounting respondents reported that their firms employed more than 50 professionals. The smaller median for the public accounting firms was somewhat skewed by sole practitioners, which is consistent with prior research. The median number of accounting professionals in industry or government organizations was 50. Fifty-nine of the 265 industry or government respondents reported more than 50 professionals. Thus, we believe this sample provides a broader spectrum of the accounting profession than surveys dominated by the "Big 4" accounting firms. Additionally, 57\% (265 of 464, see Table 1) of the survey respondents worked in industry or government.

Table 1 reports the type of organization employing the respondents.

Table 1

\section{Characteristics of Respondents by Type of Organization}

\begin{tabular}{|lrr|} 
Public Accounting Firms & 199 & $43 \%$ \\
Industry/Government & 265 & $57 \%$ \\
Total Respondents & 464 & $100 \%$ \\
\hline
\end{tabular}

Of the 464 respondents, 239 provided details about the type of accounting position they held. Table 2 provides this information. 
Table 2

\begin{tabular}{|c|c|c|}
\hline \multicolumn{3}{|c|}{$\begin{array}{l}\text { Characteristics of Respondents by Type of } \\
\text { Accounting Position Held }\end{array}$} \\
\hline Tax & 53 & $22 \%$ \\
\hline Audit/Assurance & 23 & $10 \%$ \\
\hline \multicolumn{3}{|l|}{ Corporate Accounting/ } \\
\hline Financial & 64 & $27 \%$ \\
\hline Other* & 99 & $41 \%$ \\
\hline Total respondents & 239 & $100 \%$ \\
\hline $\begin{array}{l}\text { *Includes internal audit, } \\
\text { accounting, financial services, } \\
\text { estate, and wealth management }\end{array}$ & $\begin{array}{l}\text { gene } \\
\text { con }\end{array}$ & $\begin{array}{r}\text { public } \\
\text { ing, real }\end{array}$ \\
\hline
\end{tabular}

\section{THE SURVEY QUESTIONS}

Respondents were asked on a scale of 1 to 5 , with 5 being most preferred, to rate their preference for degree(s) possessed by beginning professional staff at the time of their initial employment with the organization. Professional staff was defined as recent university graduates who were being hired for positions that involve more than bookkeeping or data entry. The degree choices were:

- Bachelor's degree in accounting;

- Bachelor's degree in accounting with 150 hours;

- Master's in accounting;

- Master's in taxation;

- Masters in information systems;

- Master's in business administration with concentration in accounting; and,

- Double undergraduate major with a space for the respondent to identify the two most preferred undergraduate majors.

\section{THE RESULTS}

Table 3 reports the mean of the overall preference rating by type of degree. The means were compared using t-tests.

Our original expectation was that master's degrees would be rated more highly than the bachelor's with 150 hours. Instead, the mean preference for the latter degree was significantly preferred over the other options. The second and third most preferred degrees were the bachelor's in accounting and master's in accounting. The next most preferred degree was the MBA with a concentration in accounting. Thus, the results were somewhat surprising.
Given that passage of the CPA examination has high priority among accounting and finance professionals, one could conclude that the preference for the 150hour bachelor's degree in accounting simply reflects employers' desires that entering accounting/finance professionals be ready to take the CPA examination.

Table 3

Respondents' Overall Preference Rating by Type of Degree

Type of degree

Overall Mean N

Bachelor's in accounting

$4.1 * \quad 434$

with 150 hours

Bachelor's in accounting

3.9* 428

Master's in accounting

$3.1 * \quad 420$

MBA with concentration

$2.9 * * \quad 412$

in accounting

Double major

$2.7 \quad 200$

Master's in taxation

2.6* 410

Master's degree in information $\quad 2.3 \quad 407$ systems

$\mathbf{N}=$ Number of respondents rating degree

* = Significantly different from next lower rated degree at $\mathbf{p}<.001$

$* *=$ Significantly different from 2.7 at .07, significantly different from 2.6 at $p<.001$

Of the 200 respondents preferring a double major, 96 did not specify the second major. The question was not designed as a "generic" double major preference so we are unsure how to interpret those responses. In most cases those who did not specify rated the category as a 1 . The preference for a double major (2.7) was not stronger than for the master's in taxation, and was stronger than the master's in information systems. Interestingly, the MBA with a concentration in accounting was only marginally preferred over the double major ( $\mathrm{p}$ - value < .07).

We further investigated the responses of the 104 respondents who specified the double majors. The mean for this group was 4.18. Also within the subgroup who identified the double major, the preferences for accounting and information systems 
(4.32) and accounting and finance (4.1) were not significantly different than the mean of the 104 subgroup as a whole (4.18). Table 4 shows the distribution of the preferences of the 104 respondents who specified a double major.

Table 4

\begin{tabular}{|c|c|c|}
\hline $\begin{array}{l}\text { Preferences of Respondents } \\
\text { Majors }\end{array}$ & Who Specified & ouble \\
\hline Type of degree & Overall Mean & $\mathbf{N}$ \\
\hline $\begin{array}{l}\text { Bachelors in accounting \& } \\
\text { information systems }\end{array}$ & $4.32 * *$ & 41 \\
\hline $\begin{array}{l}\text { Bachelors in accounting } \\
\text { \& finance }\end{array}$ & $4.10 *$ & 44 \\
\hline $\begin{array}{l}\text { Others } \\
\text { (Communications, English, } \\
\text { Business, Math) }\end{array}$ & 4.06 & 19 \\
\hline Total & 4.18 & 104 \\
\hline $\begin{array}{l}\mathbf{N}=\text { Number of respondents } \\
* *=\text { Significantly different } \\
\text { bachelor's in accounting ( } 3 . \\
*=\text { Significantly different } \mathrm{a} \\
\text { in accounting ( } 3.1 \text { - see Tab }\end{array}$ & $\begin{array}{l}\text { rating degree } \\
\text { t } p<.01 \text { from } \\
- \text { see Table 3) } \\
p<.001 \text { from m } \\
\text { e 3) }\end{array}$ & ter's \\
\hline
\end{tabular}

It can be seen that finance and information systems were selected as the most desired second majors. We interpret this as evidence that additional finance and information systems courses are what employers would prefer students take in order to achieve a 150hour undergraduate degree.

It should be noted that those listing specific majors in the double major option indicated a strong preference for the double major. Their mean preference for the double major was 4.18, which was significantly higher than the mean of 2.7 for the group responding to the double major question (p-value $<.001$ ). Further tests found that the mean preference for the accounting and information systems double major, 4.32, was greater than 3.9 mean preference for the bachelor's in accounting (p-value $<.01$ ), and the mean preference for the double major in accounting and finance, 4.10, was significantly stronger than the 3.1 mean preference for the master's in accounting (p-value <.001).

Chart 1 shows the distribution of the 41 respondents who stated a preference for the accounting and information systems double majors. Almost 75\% were employed in industry, finance, government and "other" rather than in public accounting firms. Therefore the value of the double major in accounting and information systems is likely perceived to be greater in the non-CPA firm sectors.

\section{Chart 1}

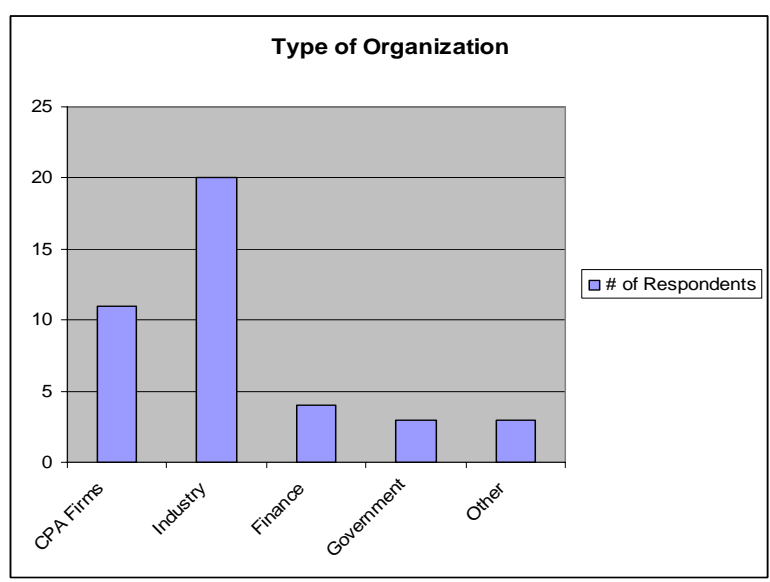

\section{CONCLUSION}

The study shows limited support for the argument that the double major in accounting and information systems is valued among accounting professionals. Approximately 10 percent of all survey respondents specifically identified that preference for entry-level accountants.

Another conclusion that can perhaps be drawn is that there was strong preference towards finance and information systems by those favoring a double major degree over softer skill second majors. Those respondents who specified a second major most frequently listed information systems or finance, and indicated a strong preference for these disciplines.

Since the bachelor's degree with 150 hours received the strongest preference from all respondents, subsequent research should more specifically address employers' preferences for the exact composition of the 150 hours, particularly hours in excess of the normal 120 hours required in most bachelor's degrees. Given the strong preference for the double major in accounting and finance or accounting and information systems, it could be argued that coursework in those two areas would likely be valued on a student's resume.

Finally, entry level accountants possessing a double major in information systems may be more important in the corporate fields than for CPA firms. 


\section{REFERENCES}

1. AICPA (2005). Core Competency Framework. http://ceae.aicpa.org/.

2. AICPA (2005). CPA Exam Specifications. http://www.cpa-exam.org/

3. Albrecht, W.S., and Sack R. (2000 Volume 16). Accounting Education: Charting the Course through a Perilous Future. Accounting Education Series, American Accounting Association. Sarasota, FL. p. 62.

4. Brown, C. (2007, Volume VIII, No, 2). Developing a marketing strategy to increase enrollment, Issues in Information Systems, pp. 16.

5. Burnett, S. (2003, Volume 78) The future of accouning education: a regional perspective, Journal of Education for Business, pp. 129-134.
6. Huefner, R. (1998) The new uniform accountancy act, The CPA Journal, pp. 12-17.

7. Merhout, J. and Buchman S. (2007, Winter, Vol. 18 Issue 4). Requisite Skills and Knowledge for Entry-level IT Auditors. Journal of Information Systems Education, pp. 469-476.

8. Pollacia, L. and Lomerson, W. (2006, Volume VII, No. 1). Analysis of factors affecting declining CIS enrollment, Issues In Information Systems, pp. 220-225.

9. Sedki, S., Madison, T. and Treacy, W. (2003). Crossing the border: An update on reciprocal international licensure, Today's CPA, pp. 28-34.

10. Ulrich, T., Michenzi, A., and Blouch, W. (2003, Spring). CPA's assess the development of professional skills of recent accounting graduates, Journal of the Academy of Business Education, pp.126-137. 